\title{
Microwave Irradiated Palladium-Catalyzed Cascade Type Cross Coupling of Phenols and Halides for the Synthesis of Polyphenolic Ethers
}

\author{
Mohammad Al-Masum*, Houra A. Alalwan \\ Department of Chemistry, Tennessee State University, Nashville, TN, USA \\ Email: *malmasum@tnstate.edu
}

How to cite this paper: Al-Masum, M. and Alalwan, H.A. (2020) Microwave Irradiated Palladium-Catalyzed Cascade Type Cross Coupling of Phenols and Halides for the Synthesis of Polyphenolic Ethers. International Journal of Organic Chemistry, 10, 135-143.

https://doi.org/10.4236/ijoc.2020.104010

Received: September 15, 2020

Accepted: November 23, 2020

Published: November 26, 2020

Copyright $\odot 2020$ by author(s) and Scientific Research Publishing Inc. This work is licensed under the Creative Commons Attribution International License (CC BY 4.0).

http://creativecommons.org/licenses/by/4.0/

\begin{abstract}
A mild, cascade type methodology was developed for the synthesis of polyphenolic ethers by the palladium-catalyzed cross coupling of phenols and halo compounds under microwave heating. In most cases, reactions run in neat conditions and in some cases, IPA/water mixture, and 1,4-dioxane were employed as solvents to furnish the products. By applying this new method, we were able to synthesize and purify a good number of polyether compounds with complete spectral data.
\end{abstract}

\section{Keywords}

Polyphenolic Ether, Cross-Coupling, Cascade Type Reaction, Microwave Heating

\section{Introduction}

The transformation of simple phenols into a platform of polyphenolic ethereal structure offers an extremely powerful tool in organic synthesis. Phenolic compounds are present in medicinal and edible plants such as; flavonoids, chalcones, coumarins, quinones, phenolic acids [1]-[7]. The antioxidant potential of phenolic compounds shows potent activities for cancer prevention and its treatment. Herein we report a novel route for phenolic ethers based on a cascade type reaction consisting of phenols and trihalo and dihalo compounds. The pioneer works of transition metal catalyzed cross-coupling reactions for $\mathrm{C}-\mathrm{O}$ bonds done by Buchwald and Hartwig are well cited in the literature. In 1996, Buchwald and coworkers published an article about the synthesis of oxygen heterocycles using palladium catalyst to create C-O bonds [8]. Recently, Buchwald also introduced a new biarylphosphine ligand with $[(\text { cinnamyl }) \mathrm{PdCl}]_{2}$ complex for the successful 
synthesis of diaryl ether (Equation 1) [9].

In 1996, Hartwig and his coworker established a new method for the formation of alkyl aryl ethers in the presence of DPPF-ligated palladium complex to form new C-O bonds [10]. In another article, Hartwig showed the mechanistic studies of the formation of diaryl ether by reductive elimination from the more electron-poor $\mathrm{CF}_{3}$-dppf and Pd-complex. The effect of bulkier ligands is 2 times faster than it was from the dppf complex (Equation 2) [11].

$\mathrm{Ma}$ and Chai compared $\mathrm{N}, \mathrm{N}$-dimethyl-promoted $\mathrm{Cu}$-catalyzed Ullman type coupling reactions for the synthesis of phenolic ethers from aryl iodides and phenols [12] [13].

Although the palladium catalyzed formation of diaryl ethers is challenging compared to the formation of aryl amines, Buchwald-Hartwig's outstanding works in this field is a breakthrough. This field does, however, still have ample room to explore. The primary interest of this project was to investigate the possibility of making polyphenolic ethers from phenols and tri- and dihalo compounds under microwave heating. A series of phenols and organic halides have been introduced for this project. One of the palladium complexes, $\mathrm{PdCl}_{2}(\mathrm{dppf}) \mathrm{CH}_{2} \mathrm{Cl}_{2}$, shows significant catalytic effect for the one reaction pot cross coupling cascade process and is able to form polyphenolic ether compounds (Equation 3).

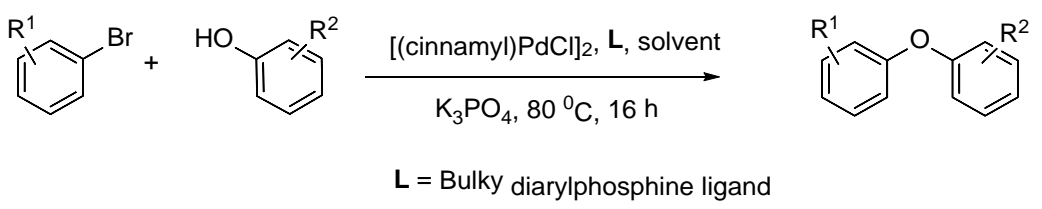

Equation 1. Pd-catalyzed synthesis of diaryl ethers under mild conditions.

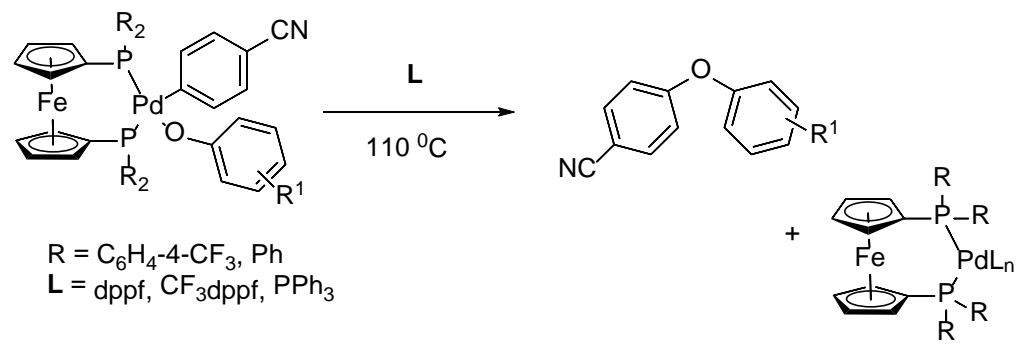

Equation 2. Formation of diaryl ethers from the reactions of dppf-ligated Pd-complex and L.

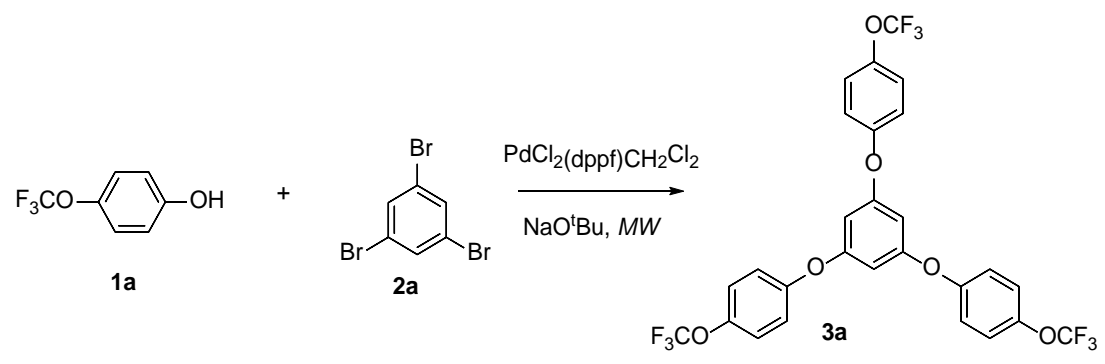

Equation 3. Phenolic ether from 1,3,5-tribromobenzene. 


\section{Results and Discussion}

After running many reactions with different ratios of starting materials, catalysts, solvents, reaction times, temperatures, and bases, several optimized reaction procedures were established. Several palladium complexes such as $\mathrm{PdCl}_{2}(\mathrm{dppf}) \mathrm{CH}_{2} \mathrm{Cl}_{2}, \mathrm{PdCl}_{2}\left(\mathrm{~d}^{\mathrm{t}} \mathrm{bpf}\right), \mathrm{PdCl}_{2}\left(\mathrm{Ph}_{3} \mathrm{P}\right)_{2}$, and $\mathrm{Pd}(\mathrm{OAC})_{2}$, were tested. We found that $\mathrm{PdCl}_{2}(\mathrm{dppf}) \mathrm{CH}_{2} \mathrm{Cl}_{2}$ shows effective catalytic effect for this new transformation. Different mole percentages of $\mathrm{PdCl}_{2}(\mathrm{dppf}) \mathrm{CH}_{2} \mathrm{Cl}_{2}$ were applied but most of the results were obtained using $5 \mathrm{~mol} \%$ of $\mathrm{PdCl}_{2}(\mathrm{dppf}) \mathrm{CH}_{2} \mathrm{Cl}_{2}$. The study showed that excess amount of phenols gave good result when interacting $0.5 \mathrm{mmol}$ of the halides with the load of $5 \mathrm{~mole} \% \mathrm{PdCl}_{2}(\mathrm{dppf}) \mathrm{CH}_{2} \mathrm{Cl}_{2}$. The results are summarized in Figure 1. All of the products shown in Figure 1 are solvent free systems. Several solvent systems such as, 1,4-dioxane, isopropanol/water, toluene, THF, $\mathrm{CH}_{2} \mathrm{Cl}_{2}$, and acetonitrile, were applied and failed. In the control experiment, the predicted cross coupling product $\mathbf{3 a}$ was totally undetected in the absence of palladium catalyst. The experiments worked well when microwaved at $80^{\circ} \mathrm{C}$ for $3-4 \mathrm{~h}$. In the case of sp3 1,3-dibromopropane $2 \mathrm{~b}$, reactions microwaved for $3 \mathrm{~h}$ (Obs. 2, 3, and 4 in Figure 1).

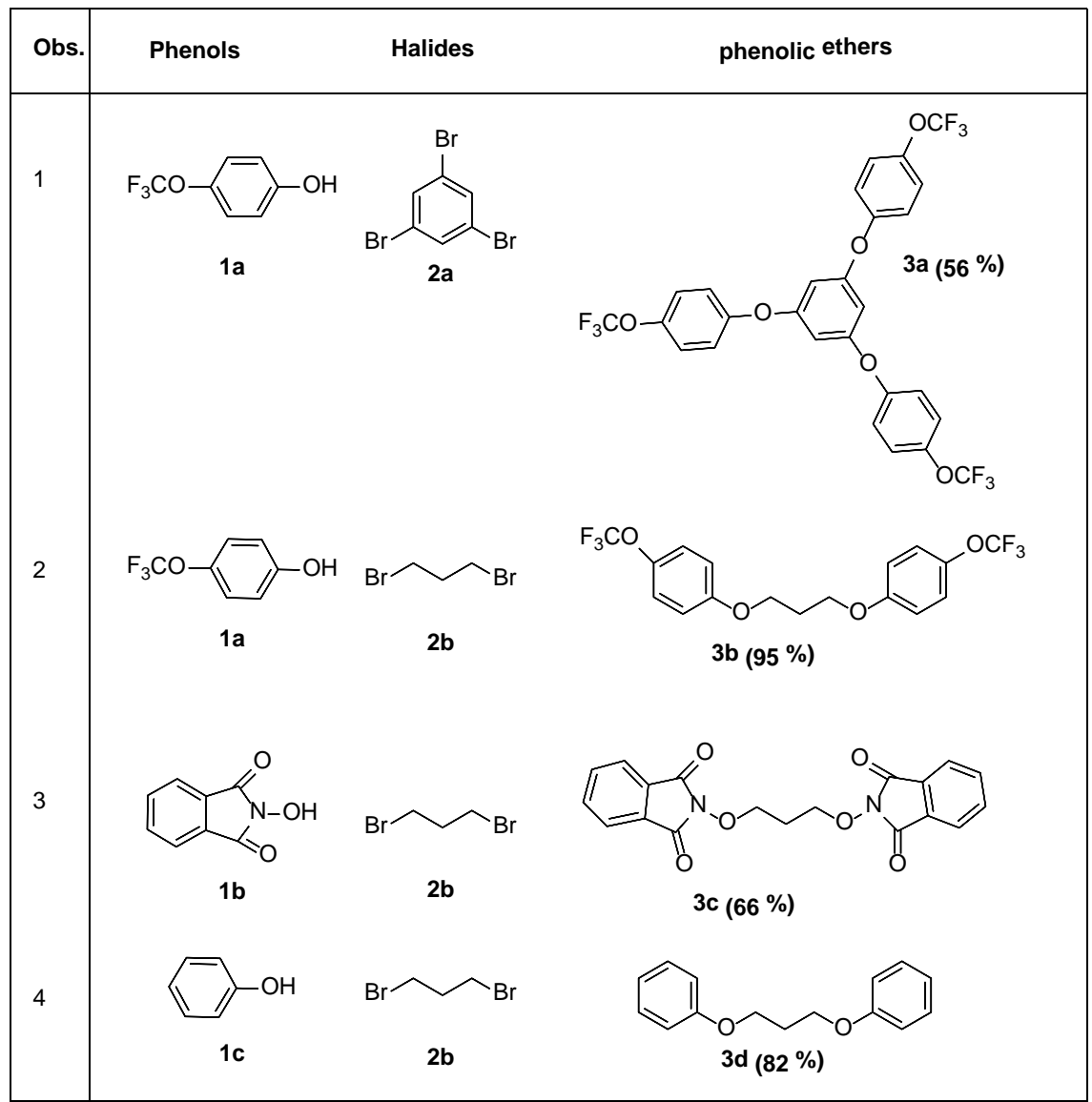

Figure 1. Solvent free Pd-catalyzed cross-coupling of phenols and halides ${ }^{\mathrm{a}}$. ${ }^{\mathrm{a}}$ All yields are isolated yields and purified by colum chromatography or preparative TLC. 5 mole\% $\mathrm{PdCl}_{2}$ (dppf) $\mathrm{CH}_{2} \mathrm{Cl}_{2}$ were used as catalyst. No solvent. 
These reactions when run with equimolar amount of $\mathrm{NaO}^{t} \mathrm{Bu}$, no product was found but in presence of 5 mole\% palladium catalyst similar reaction showed cross-coupling product. In case of 1,4-diiodo butane, smooth reaction was observed with excess amount of $\mathrm{NaO}^{t} \mathrm{Bu}$ without catalyst. It is possible that although diiodo sp3 alkyl halide works well without palladium catalyst in simple $\mathrm{S}_{\mathrm{N}} 2$ reaction for phenolic ether synthesis, relatively slower dibromo sp3 alkyl halide such as $2 \mathrm{~b}$ possibly promoted the reaction by insertion of palladium and favors cross-coupling phenolic ether compounds.

When the same reaction was run without palladium catalyst, no change was observed except for two clear spots of starting materials in TLC. This reaction is also futile to produce cross-coupling product in the absence of solvent even with a large excess of phenol, which usually worked in other cases shown in Figure 1. The product $3 \mathbf{e}$ was obtained in moderate yield. Under the same reaction conditions, 1-bromo-3-iodobromobenzene $2 \mathrm{c}$ furnished good results with other phenols (Obs. 2, 3, 4 Figure 2). Instead of 1-bromo-3-iodobromobenzene 2c, these reactions were run with 1-chloro-3-iodobenzene as well. $2 \mathrm{c}$ yielded better coupling products.

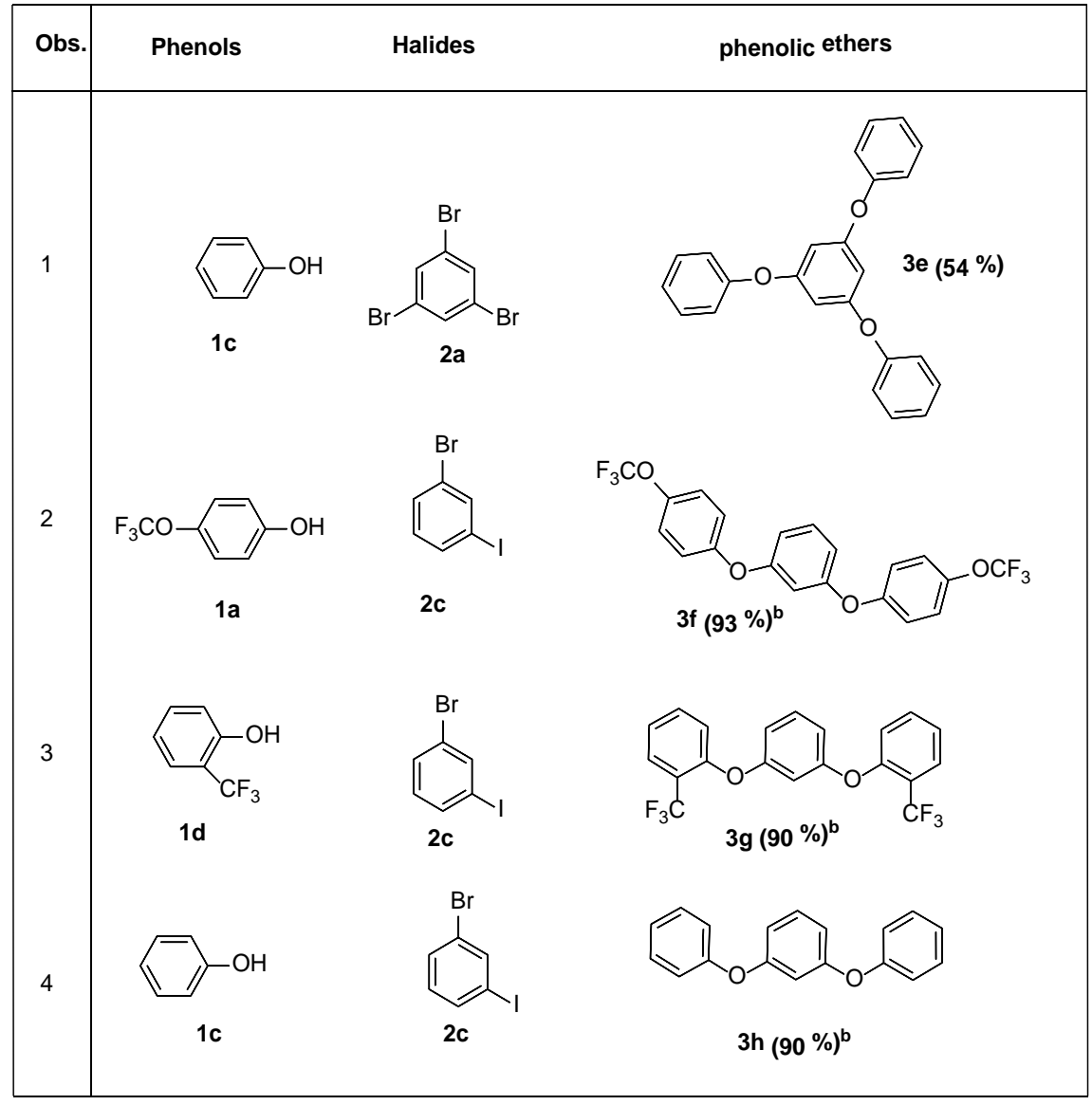

Figure 2. Pd-catalyzed cross-coupling of phenols and halides with solvent ${ }^{\mathrm{a}}$. ${ }^{\mathrm{a}}$ Reactions microwaved for $5 \mathrm{~h}$ at $140^{\circ} \mathrm{C}$ in presence of IPA/water (2:1) solvent system. 2.5 mole\% $\mathrm{PdCl}_{2}$ (dppf) $\mathrm{CH}_{2} \mathrm{Cl}_{2}$ used as catalyst. ${ }^{\mathrm{b}} 2.0 \mathrm{mmol}(195 \mathrm{mg})$ of $\mathrm{NaO}^{\mathrm{t}} \mathrm{Bu}$ used. 
The cross coupling of bromo iodomethane $2 \mathrm{~d}$ gave the desired product when interacted with phenol $1 \mathrm{c}$ in the presence of 1,4-dioxane as a solvent. To furnish this phenolic ether product, $1.1 \mathrm{mmol}(103.5 \mathrm{mg})$ of phenol, $0.5 \mathrm{mmol}$ of bromo iodomethane, $5 \mathrm{~mol} \%$ of $\mathrm{PdCl}_{2}(\mathrm{dppf}) \mathrm{CH}_{2} \mathrm{Cl}_{2}$, and $2 \mathrm{mmol}$ of $\mathrm{NaO}^{t} \mathrm{Bu}$ were used. The reaction was in the microwave oven for $5 \mathrm{~h}$ at $80^{\circ} \mathrm{C}$ (Equation 4).

Interestingly, we attempted a mixture of phenols and halides in the presence of palladium catalyst to see the scope of this new transformation to phenolic ether.

\section{Experimental Procedure}

Procedure 1. This procedure is a representative one. In an oven dry, clean microwave vial loaded with $2.0 \mathrm{mmol}$ of $\mathrm{NaO}^{\mathrm{t}} \mathrm{Bu}(195 \mathrm{mg}), 5 \mathrm{~mol} \%$ of $\mathrm{PdCl}_{2}(\mathrm{dppf}) \mathrm{CH}_{2} \mathrm{Cl}_{2}(22.0 \mathrm{mg})$, was capped with an air-tight silicon septum, The reaction vial was flushed with argon followed by the addition of $0.5 \mathrm{mmol}$ of the 1,3,5-tribromo benzene $(160.0 \mathrm{mg})$ via micro syringe and an excess amount (1.5 $\mathrm{mL}$ ) of 4-trifluoromethoxy phenol via dry syringe. The resulting reaction mixture was microwaved at $80^{\circ} \mathrm{C}$ for $3.5 \mathrm{~h}$. The crude reaction product was subjected to column chromatography with hexane and ethyl acetate (25:1) as eluents and the polyphenolic ether product was collected. The slurry of $40 \mathrm{~mL}$ (by volume) weight of silica gel and eluent (Hexane:ethyl acetate 25:1) was transferred into the column, tapped to remove air, and packed. The column was ther ready to use for separation. $10 \mathrm{~g}$ of silica gel were added to the crude reaction product. After rotary evaporation, we got a fine powder, which was transferred to the surface of the column. A layer of sand was added above it to make sure that the powder layer was unbroken. All collected fractions were monitored by thin layer chromatography to identify the new spots for desired phenolic ether compound. We collected all those fractions with same $R_{f}$ value in a clean and dry round bottom flask. The solvent with product was evaporated using the rotary evaporator, and then was added dichloromethane to get rid of any excess of ethyl acetate that could remain in the product. The product was dried under the vacuum pump for several hours to make sure that the solvent did not remain in the product. Finally, the concentrated product was analyzed by ${ }^{1} \mathrm{H},{ }^{13} \mathrm{C}$, and ${ }^{19} \mathrm{~F}$ NMR spectroscopy. Compound 3a. ${ }^{1} \mathrm{H}$ NMR $\left(\mathrm{CDCl}_{3}, 400 \mathrm{MHz}\right) \delta 7.12(\mathrm{~m}, 7 \mathrm{H}),$, $(\mathrm{m}, 8 \mathrm{H}) .{ }^{13} \mathrm{C} \mathrm{NMR}\left(\mathrm{CDCl}_{3}, 100 \mathrm{MHz}\right) \delta 153.9,142.9,124.3,122.6,121.8,119.2$, 116.4. ${ }^{19} \mathrm{~F} \mathrm{NMR}\left(\mathrm{CDCl}_{3} 400 \mathrm{MHz}\right) \delta-58.4$.

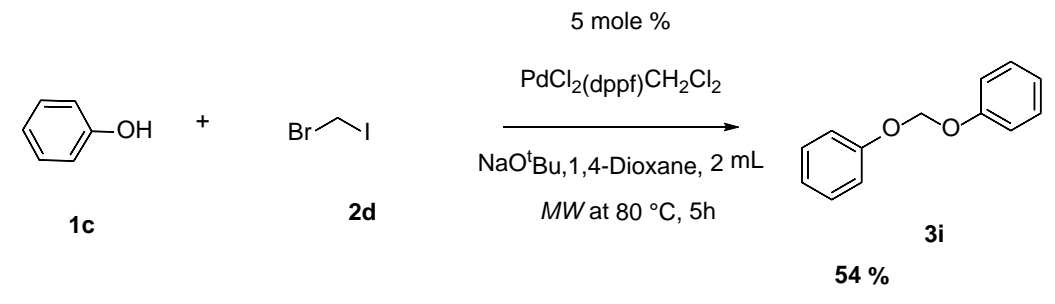

Equation 4. Cross coupling of bromoiodomethane and phenol. 
Procedure 2. The formation of ether $3 \mathrm{e}$ by cross coupling reaction involved $1.65 \mathrm{mmol}(155.28 \mathrm{mg})$ of phenol $1 \mathrm{c}$ and $0.5 \mathrm{mmol}(160.6 \mathrm{mg})$ of 1,3,5-tribromobenzene 2a. The reactants were loaded in dry, clean microwave vial and 2.65 $\mathrm{mmol}(255 \mathrm{mg})$ of $\mathrm{NaO}^{\mathrm{t}} \mathrm{Bu}$ and $2.5 \mathrm{~mol} \%$ of $\mathrm{PdCl}_{2}(\mathrm{dppf}) \mathrm{CH}_{2} \mathrm{Cl}_{2}$ were added to the mixture. Then it was capped with septum and flushed with argon followed by the addition of iso-propanol/water (2:1) as solvents (Obs. 1, Figure 2). The resulting mixture irradiated at $140^{\circ} \mathrm{C}$ for $5 \mathrm{~h}$. The crude reaction mixture was filtered through a sintered funnel and concentrate. For purification, the crude mixture was subjected to column chromatography using hexane/ethyl acetate $(25 / 1)$ as eluents.

Procedure 3. An oven dry, clean microwave vial was loaded with $2.0 \mathrm{mmol}$ of $\mathrm{NaO}{ }^{t} \mathrm{Bu}(195 \mathrm{mg}), 5 \mathrm{~mol} \%$ of $\mathrm{PdCl}_{2}(\mathrm{dppf}) \mathrm{CH}_{2} \mathrm{Cl}_{2}(22.0 \mathrm{mg})$ and capped with air-tight silicon septum. The reaction vial was flushed with argon followed by the addition of $0.5 \mathrm{mmol}$ of the bromo iodomethane $2 \mathrm{~d}$ via micro syringe. 0.5 $\mathrm{mmol}(48.0 \mathrm{mg})$ of phenol $1 \mathrm{c}$ and $0.5 \mathrm{mmol}$ of 4 -trifluormethoxy phenol $(64 \mu \mathrm{L})$ 1a were added via micro syringe as well. The resulting reaction mixture was flushed in argon then was added the solvent 1,4-dioxane $(2 \mathrm{~mL})$ The loaded reaction vial was microwaved at $80^{\circ} \mathrm{C}$ for $5 \mathrm{~h}$. The crude reaction product in the reaction tube diluted with ethyl acetate was transferred into a separatory funnel. After a standard extraction with brine solution, the organic layer was collected in a small Erlenmeyer flask over anhydrous $\mathrm{Na}_{2} \mathrm{SO}_{4}$. The ethyl acetate layer was filtered through a sintered funnel and the collected filtrate in a round bottom flask was completely dried by rotary evaporator in vacuo. The column chromatography technique was used to sperate the product. The desired polyphenolic ether product $3 \mathbf{j}$ was confirmed by ${ }^{1} \mathrm{H}$ NMR, ${ }^{13} \mathrm{C}$ NMR, and ${ }^{19} \mathrm{~F}$ NMR (Equation 5).

\section{Probable Reaction Mechanism}

The probable mechanism of this palladium-catalyzed polyphenolic ether reaction most likely proceeds via a pathway shown in Figure 3. The oxidative addition of the $\mathrm{Pd}(0) \mathrm{Ln}$ with the trihalide renders the $\mathrm{Pd}(\mathrm{II})$ inserted organometallic intermediate. In the presence of sodium tertiary butoxide, the chelation/deprotonation of phenol renders the species that is ready to do reductive elimination to yield the first ether moiety. It is rational to predict that the remaining halides follow the same catalytic process with regenerated palladium catalyst and furnish the carbon-oxygen bonds for polyphenolic ether product.

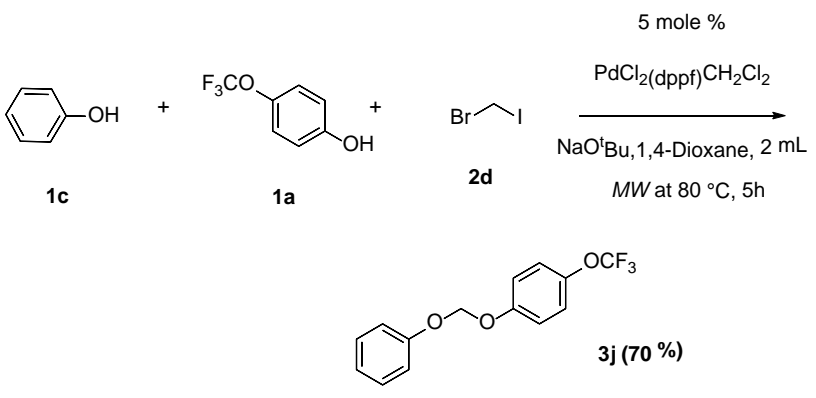

Equation 5. Phenolic ether from mixed phenols. 


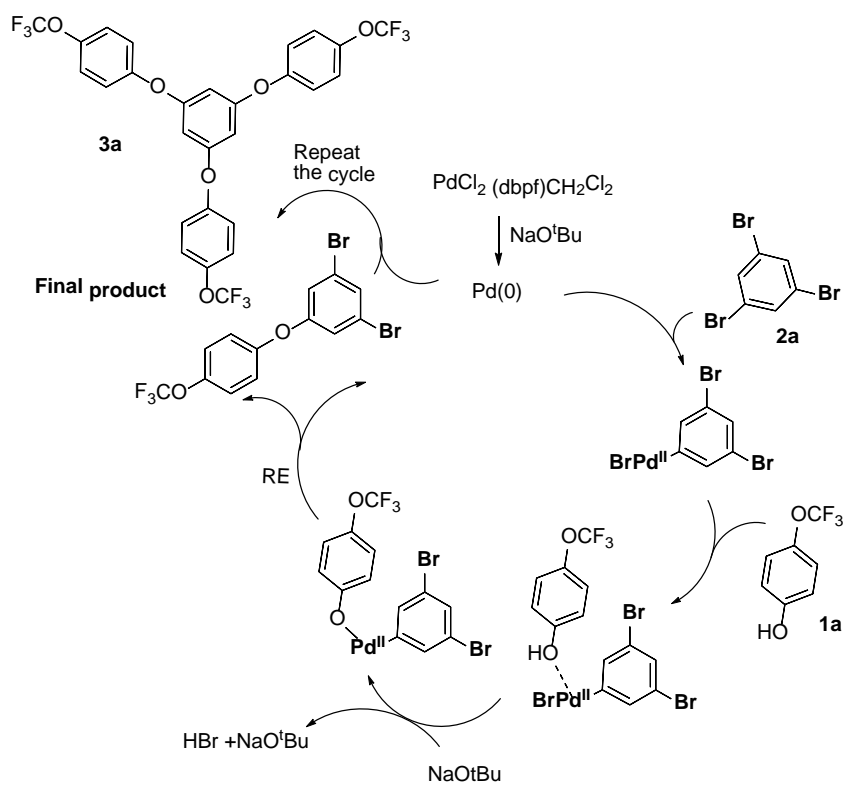

Figure 3. Probable reaction mecanism of polyphenyl ether.

\section{Conclusions}

This work developed a microwave irradiated new synthetic processes for the synthesis of a good number of polyphenolic ethers from phenols and aromatic tribromo- and 3-iodo-bromobenzene in one reaction pot. The cross coupling of phenols and alkyl halides such as $\mathbf{2 b}$ and $\mathbf{2 d}$ also successfully steered in single reaction vial. The multiple carbon-oxygen bonds formation reaction is one pot reaction is not known through metal-catalyzed cross-coupling reaction. Since antioxidant nature polyphenolic ether compounds are potent activities for cancer treatment, the new synthetic method of multi coupling and the making of multiple carbon-oxygen bonds in one reaction vial will get much attention among chemists. The initial findings of making phenolic ether from the two different phenols and halides (Equation 5), will be explored and reported in due courses from our laboratory.

NMR data of products from Figure 1, Figure 2, $3 \mathrm{~h}$ and $3 \mathrm{i}$ are given below.

Compound 3a, ${ }^{1} \mathrm{H} \mathrm{NMR}\left(\mathrm{CDCl}_{3}, 400 \mathrm{MHz}\right) \delta 7.12$ - $6.83(\mathrm{~m}, 15 \mathrm{H}) .{ }^{13} \mathrm{C} \mathrm{NMR}$ $\left(\mathrm{CDCl}_{3}, 100 \mathrm{MHz}\right) \delta 153.9,142.9,124.3,122.6,121.8,119.2,116.4 .{ }^{19} \mathrm{~F}$ NMR $\left(\mathrm{CDCl}_{3} 400 \mathrm{MHz}\right) \delta-58.4$;

Compound 3b, ${ }^{1} \mathrm{H}$ NMR $\left(\mathrm{CDCl}_{3}, 400 \mathrm{MHz}\right) \delta 7.27$ - $6.88(\mathrm{~m}, 8 \mathrm{H}), 4.15(\mathrm{~m}$, $4 \mathrm{H}), 2.27(\mathrm{~m}, 2 \mathrm{H}) .{ }^{13} \mathrm{C} \mathrm{NMR}\left(\mathrm{CDCl}_{3}, 100 \mathrm{MHz}\right) 157.3,142.7,122.4,119.4,115.1$, 64.6, 29.1 ${ }^{19} \mathrm{~F} \mathrm{NMR}\left(\mathrm{CDCl}_{3} 400 \mathrm{MHz}\right) \delta-58.4$;

Compound 3c, ${ }^{1} \mathrm{H}$ NMR $\left(\mathrm{CDCl}_{3}, 400 \mathrm{MHz}\right) \delta 7.75-7.65(\mathrm{~m}, 8 \mathrm{H}), 4.43-3.61$ $(\mathrm{m}, 2 \mathrm{H}), 4.28-4.0(\mathrm{~m}, 2 \mathrm{H}), 2.21(\mathrm{~m}, 2 \mathrm{H}) .{ }^{13} \mathrm{C} \mathrm{NMR}\left(\mathrm{CDCl}_{3}, 100 \mathrm{MHz}\right) \delta 168.6$, 163.5, 134.4, 133.9, 132.8, 128.8, 123.3, 60.2, 31.3, 29.2, 20.7, 14.0;

Compound 3d, ${ }^{1} \mathrm{H}$ NMR $\left(\mathrm{CDCl}_{3}, 400 \mathrm{MHz}\right) \delta 7.33-6.93(\mathrm{~m}, 10 \mathrm{H}), 4.19(\mathrm{~m}$, $4 \mathrm{H}), 2.29(\mathrm{~m}, 2 \mathrm{H}) .{ }^{13} \mathrm{C} \mathrm{NMR}\left(\mathrm{CDCl}_{3}, 100 \mathrm{MHz}\right) \delta 1158.9,129.4,120.7,114.5$, 64.3, 29.3; 
Compound 3e, ${ }^{1} \mathrm{H}$ NMR $\left(\mathrm{CDCl}_{3}, 400 \mathrm{MHz}\right) \delta 7.74-7.1(\mathrm{~m}, 15 \mathrm{H}, 3 \mathrm{H}){ }^{13} \mathrm{C}$ $\operatorname{NMR}\left(\mathrm{CDCl}_{3}, 100 \mathrm{MHz}\right) \delta 141.8,141.2,129.9,129.1,128.8,127.4,127.2,126.1$;

Compound 3f, ${ }^{1} \mathrm{H}$ NMR ( $\left.\mathrm{CDCl}_{3}, 400 \mathrm{MHz}\right) \delta 8.31-6.41$ (m, 12H, Aromatic).

${ }^{13} \mathrm{C} \mathrm{NMR}\left(\mathrm{CDCl}_{3}, 100 \mathrm{MHz}\right) \delta 155.8,1417,128.6,127.1,124.3,122.2,121.8,119$.

2, 116.2, ${ }^{19} \mathrm{~F} \mathrm{NMR}\left(\mathrm{CDCl}_{3} 400 \mathrm{MHz}\right) \delta-58.7$;

Compound 3g, ${ }^{1} \mathrm{H}$ NMR $\left(\mathrm{CDCl}_{3}, 400 \mathrm{MHz}\right) \delta 8.31$ - 6.41 (m, 12H, Aromatic). ${ }^{13} \mathrm{C}$ NMR $\left(\mathrm{CDCl}_{3}, 100 \mathrm{MHz}\right) \delta 161.7,139.7,135.4,131.3,130.8,129.8,125.7$, 123.0, 118.9, 117.4, 112.9, 94.4. ${ }^{19} \mathrm{~F} \mathrm{NMR}\left(\mathrm{CDCl}_{3} 400 \mathrm{MHz}\right) \delta-61.6$;

Compound 3h, ${ }^{1} \mathrm{H} \mathrm{NMR}\left(\mathrm{CDCl}_{3}, 400 \mathrm{MHz}\right) \delta 7.05-6.68$ (m 14H, Aromatic).

${ }^{13} \mathrm{C} \mathrm{NMR}\left(\mathrm{CDCl}_{3}, 100 \mathrm{MHz}\right) \delta 155.5,128.6,119.2,114.6$;

Compound 3i, ${ }^{1} \mathrm{H}$ NMR $\left(\mathrm{CDCl}_{3}, 400 \mathrm{MHz}\right) \delta 7.23$ - 6.82 (m 10H, Aromatic), $6.03(\mathrm{~s}, 2 \mathrm{H}) .{ }^{13} \mathrm{C} \mathrm{NMR}\left(\mathrm{CDCl}_{3}, 100 \mathrm{MHz}\right) \delta 155.6,129.5,120.5,116.4,115.3$;

Compound 3j, ${ }^{1} \mathrm{H}$ NMR $\left(\mathrm{CDCl}_{3}, 400 \mathrm{MHz}\right) \delta 7.60-6.82(\mathrm{~m}, 10 \mathrm{H}), 7.12(\mathrm{~s}$, $2 \mathrm{H}) .{ }^{13} \mathrm{C} \mathrm{NMR}\left(\mathrm{CDCl}_{3}, 100 \mathrm{MHz}\right) \delta 156.0,155.0,142.3,129.5,122.4,120.3,116.1$, 115.3. ${ }^{19} \mathrm{~F} \mathrm{NMR}\left(\mathrm{CDCl}_{3} 400 \mathrm{MHz}\right) \delta-58.4$.

\section{Conflicts of Interest}

The authors declare no conflicts of interest regarding the publication of this paper.

\section{References}

[1] Estrela, J.M., Mena, S., Obrador, E., Benlloch, M., Castellano, G., Salvador, R. and Dellinger, R.W. (2017) Polyphenolic Phytochemicals in Cancer Prevention and Therapy: Bioavailability versus Bioefficacy. Journal of Medicinal Chemistry, 60, 9413-9436. https://doi.org/10.1021/acs.jmedchem.6b01026

[2] Flaherty, D.P., Kiyota, T., Dong, Y., Ikezu, T. and Vennerstrom, J.L. (2010) Phenolic Bis-Styrylbenzenes as $\beta$-Amyloid Binding Ligands and Free Radical Scavengers. Journal of Medicinal Chemistry, 53, 7992-7999. https://doi.org/10.1021/jm1006929

[3] Halake, K., Birajdar, M. and Lee, J. (2016) Structural Implications of Polyphenolic Antioxidants. Journal of Industrial and Engineering Chemistry, 35, 1-7. https://doi.org/10.1016/j.jiec.2016.01.003

[4] Tejedor, D., Lopez-Tosco, S., Mendez-Abt, G., Cotos, L. and Garcia-Tellado, F. (2016) Propargyl Vinyl Ethers and Tertiary Skipped Diynes: Two Pluripotent Molecular Platforms for Diversity-Oriented Synthesis. Accounts of Chemical Research, 49, 703-713. https://doi.org/10.1021/acs.accounts.5b00545

[5] Newkome, G.R. and Lin, X. (1991) Symmetrical, Four-Directional, Poly(ether-amide) Cascade Polymers. Macromolecules, 24, 1443-1444. https://doi.org/10.1021/ma00006a042

[6] Xiong, W., Yan, D., Qi, C. and Jiang, H. (2018) Palladium-Catalyzed Four-Component Cascade Reaction for the Synthesis of Highly Functionalized Acyclic O,O-Acetals. Organic Letters, 20, 672-675. https://doi.org/10.1021/acs.orglett.7b03808

[7] Colquhoun, H.M., Hodge, P., Paoloni, F.P.V., McGrail, P.T. and Cross, P. (2009) Reversible, Nondegradative Conversion of Crystalline Aromatic Poly(ether ketone)s into Organo-Soluble Poly(ether dithioketal). Macromolecules, 42, 1955-1963. https://doi.org/10.1021/ma8023377

[8] Palucki, M., Wolfe, J.P. and Buchwald, S.L. (1996) Synthesis of Oxygen Heterocycles 
via a Palladium-Catalyzed C-O Bond-Forming Reaction. Journal of the American Chemical Society, 118, 10333-10334. https://doi.org/10.1021/ja962408v

[9] Salvi, L., Davis, N.R., Ali, S.Z. and Buchwald, S.L. (2012) A New Biarylphosphine Ligand for the Palladium-Catalyzed Synthesis of Diaryl Ethers under Mild Conditions. Organic Letters, 14, 170-173. https://doi.org/10.1021/ol202955h

[10] Mann, G. and Hartwig, J.F. (1996) Palladium Alkoxides: Potential Intermediacy in Catalytic Amination, Reductive Elimination of Ethers, and Catalytic Etheration. Comments on Alcohol Elimination from Ir(III). Journal of the American Chemical Society, 188, 13109-13110. https://doi.org/10.1021/ja963273w

[11] Mann, G., Shelby, Q., Roy, A.H. and Hartwig, J.F. (2003) Electronic and Steric Effects on the Reductive Elimination of Diaryl Ethers from Palladium (II). Organometallics, 22, 2775-2789. https://doi.org/10.1021/om030230x

[12] Ma, D. and Cai, Q. (2003) N,N-Dimethyl Glycine-Promoted Ullman Coupling Reaction of Phenols and Aryl Halides. Organic Letters, 5, 3799-3802. https://doi.org/10.1021/ol0350947

[13] Maiti, D. and Buchwald, S.L. (2010) Cu-Catalyzed Arylation of Phenols: Synthesis of Sterically Hindered and Heteroaryl Diaryl Ethers. The Journal of Organic Chemistry, 75, 1791-1794. https://doi.org/10.1021/j09026935 